J. Lake Sci. (湖泊科学), 2013, 25(6): 936-942

http: //www.jlakes.org. E-mail: jlakes@niglas. ac.cn

(c) 2013 by Journal of Lake Sciences

\title{
辽河太子河流域藻类植物群落结构及其季节变化
}

\author{
王宏伟, 陈 莹, 张晓明, 侯和胜 ${ }^{* *}$ \\ (辽宁师范大学生命科学学院, 大连 116081)
}

\begin{abstract}
摘 要: 2010 年 9 月到 2011 年 9 月分 4 次对太子河流域的藻类植物群落组成、丰度及优势种进行调查分析. 共设置 17 个采样点, 经鉴定共有藻类植物 8 门 120 属 328 种 (包括 21 种变种). 藻类植物群落以硅藻最多, 有 36 属 144 种, 占总体 的 $43.77 \%$; 其次是绿藻, 有 49 属 117 种, 占总体的 $35.56 \%$; 蓝藻居第 3 位, 有 22 属 38 种, 占总体的 $11.85 \%$. 调查期间, 太子河流域藻类植物细胞丰度在夏、秋季较高, 丰度平均值分别为 $6.80 \times 10^{7}$ 和 $3.29 \times 10^{7} \mathrm{cells} / \mathrm{L}$; 在春季较低, 丰度平均 值为 $1.36 \times 10^{7}$ cells $/ \mathrm{L}$. 优势度分析显示, 太子河流域各季节的藻类植物优势种都在 5 种以上, 主要优势种有巨颤藻 $(O s-$ cillatoria princeps Vauch.)、链丝藻 (Hormidium flaccidum (Kütz.) Br. )、偏生毛枝藻 (Stigeoclonium subsecundum (Kütz.) Haz. ) 等. 藻类植物的 Jaccard 种类相似性指数在 $0.19 \sim 0.46$ 之间. 太子河流域藻类植物种类组成及细胞丰度均有明显的 季节变化.
\end{abstract}

关键词: 太子河;藻类植物;群落结构;季节变化;辽河

\section{The algal community structure and seasonal variation in Taizi River catchment, Liaohe River basin}

WANG Hongwei, CHEN Ying, ZHANG Xiaoming \& HOU Hesheng

(College of Life Sciences, Liaoning Normal University, Dalian 116081, P. R. China)

Abstract:To understand the algal community structure, cell abundance and dominant species, Taizi River catchment, Liaohe River basin were investigated four times, from September 2010 to September 2011. Algae, including 8 phyla, 120 genera, 328 species (including 21 varieties) were identified from 17 sampling sites. Bacillariophyta were the dominant algae and included 36 genera, 144 species, accounting for $43.77 \%$ of the algae. Chlorophyta, with 49 genera, 117 species, accounted for $35.56 \%$ of the algae. Cyanophyta, included 22 genera, 38 species and accounted for $11.85 \%$ of the algae. The cell abundance of algae was higher in summer and autumn, which were $6.80 \times 10^{7}$ and $3.29 \times 10^{7}$ cells/L, respectively. However, it was lower in spring with $1.36 \times 10^{7}$ cells $/$ L. This study also demonstrated that the dominant species of algae in Taizi River catchment were more than five, including Oscillatoria princeps Vauch., Hormidium flaccidum (Kütz.) Br. and Stigeoclonium subsecundum ( Kütz. ) Haz. ect. Species Jaccard index of the algae varied from 0.19 to 0.46 . Both algal community structure and cell abundance have obvious seasonal variation in Taizi River catchment.

Keywords: Taizi River; algae; community structure; seasonal variation; Liaohe River

太子河古称衍水、大梁河、梁水, 燕太子丹逃亡于此, 故名太子河. 太子河是大辽河的主要支流, 流经本 溪、辽阳和鞍山等主要工业城市. 随着经济发展,太子河流域对水资源的需求逐步增加, 流域内的人类活动 和众多的工业、企业形成的污染对太子河流域水生生物群落造成了严重的影响. 在国家“十二五”发展规划 中,江河湖泊休养生息已经被确立为我国河流生态系统保护的国家战略, 因此太子河流域社会经济发展如 何与河流生态保护结合起来将是我们面临的一个重要课题 ${ }^{[1]}$.

近年来, 对太子河流域的研究主要集中在水质理化指标 ${ }^{[2-5]}$ 和大型水生植物群落特征 ${ }^{[1]}$ 的调查上, 而对

* 国家水体污染控制与治理科技重大专项项目 (2008ZX07208,2009ZX07208-010) 资助. 2012-12-02 收稿;201304-06 收修改稿. 王宏伟,男,1963 年生,教授;E-mail: kitamiwang@163.com.

** 通信作者;E-mail: hesheng_hou@ 126.com. 
藻类植物群落结构的研究较少. 关于太子河流域藻类植物群落结构的研究主要侧重研究某一河段或某个水 库 $^{[6-9]}$,如赵彦霞等 ${ }^{[6]}$ 于 1989 年 4-10 月在太子河 “本溪水段”设置 5 个断面 4 个排污沟对本溪水段的浮游 植物进行调查; 苏玉等 ${ }^{[7]}$ 从 2009 年 7 月到 2010 年 1 月进行采样,探讨本溪段丰水期和平水期着生藻类和大 型底栖动物群落特征以及其与水质污染因子的关系; 李悦等 ${ }^{[8]}$ 于 2009 年 9 月在太子河北支河岸带采样,对 植物群落的组成、种类和外貌进行了研究; 邱春刚等 ${ }^{[9]}$ 对汤河水库春季的浮游生物的群落结构及空间分布 进行了调查研究; 也有学者研究单一季节的整个太子河流域的藻类植物的群落结构 ${ }^{[10-11]}$, 如李庆南等 ${ }^{[10]}$ 从 2009 年 5 月到 8 月对辽河太子河水系的浮游植物进行了野外调查,做了浮游植物种类多样性研究; 殷旭旺 等 ${ }^{[11]}$ 从 2009 年 8 月末至 9 月初进行采样调查, 调查研究了太子河流域的着生藻类群落和水环境的理化特 征, 并对太子河流域的水生态系统做了评价. 对整个太子河流域藻类植物的群落结构组成及季节性变化的 研究未见报道. 本研究分 3 个季节对太子河的 12 个干流、5 个支流进行藻类植物群落结构和生物量的调查, 旨在揭示太子河流域社会经济发展对藻类植物及河流生态系统的潜在威胁, 为太子河流域藻类植物多样性 保护提供可行性依据.

\section{1 研究区域与研究方法}

\section{1 研究区域概况}

辽河太子河有南北二源, 北支称北太子河, 发源于新宾县红石砬子山, 由本溪县东北部南甸子镇二道河 子村人境; 南支称南太子河, 发源于本溪县东草帽顶子山, 流经东营坊、蓝河峪、碱厂和南甸子等乡 (镇); 南 北二支在南甸子镇马城子村汇合为太子河干流. 太子河由东向西南流经本溪县泉水、小市、偏岭等乡 (镇) 和 明山区牛心台镇后进人市区, 由东北向西南从市区中心通过,经白石碰子村出境人辽阳境内. 本溪境内河长 $168 \mathrm{~km}$, 流域面积 $4428 \mathrm{~km}^{2}$. 河道比降上游大、下游小, 在 $1 / 4000 \sim 1 / 3000$ 之间. 处于大陆性季风气候条件 下, 年均气温和年平均降水量分别为 $9^{\circ} \mathrm{C}$ 和 $886.4 \mathrm{~mm}$, 且受季风影响降雨主要集中在 6-9 月, 其降水量占 全年降水量的 70\% 80\%, 河水上涨, 进人汛期, 河水径流量占年径流量的 70\%, 11 月至翌年 3 月上旬为平 水期, 河道主要靠地下水补给, 冬季有 $3 \sim 4$ 个月的结冰期. 太子河水流的平均 $\mathrm{pH}$ 值为 7.61.

\section{2 采样点设置}

2010 年 9 月, 2011 年 $3 、 6$ 和 9 月, 在太子河流域 $\left(40^{\circ} 00^{\prime} 24^{\prime \prime} \sim 41^{\circ} 23^{\prime} 32^{\prime \prime} \mathrm{N}, 123^{\circ} 14^{\prime} 26^{\prime \prime} \sim 124^{\circ} 17^{\prime} 55^{\prime \prime} \mathrm{E}\right)$ 布 设 17 个藻类植物采样点 (图 1). 由于 2010 年 8-9 月份辽宁省辽河一浑河一太子河流域降水量很大,导致整 个流域发生较大洪水, 影响了生态调查采样工作的进行. 因此, 采样是在洪水过后的 9月10-13 日进行的. 经过洪水后的太子河流域的生物物种在数量和分布上将会受到一定的影响, 所以在 2011 年 9 月 28-29 日又 进行了补充采样.

\section{3 取样方法及处理}

分别采用定性和定量两种方法 ${ }^{[12]}$ 对各采样点进行样品采集, 浮游藻类定量样品采用 WB-PM 和 CD01004 型浮游生物分层采集器采集, 每个采样点采水 5 30 L 不等. 底栖藻类定量样品采用 CG02001 型彼 得森采泥器 $\left(1 / 16 \mathrm{~m}^{2}\right)$ 和手抄网完成. 各采样点用上述两种采样方法各采集 2 次样品. 采样后过 $25^{\#}$ 浮游生 物网浓缩样品. 分层采样时, 将各层水样分别定量取平均值或将各层所采水样等量混匀后定量作为此点生 物量的检测样品. 浓缩后的样品以 $5 \%$ 福尔马林固定, 定容到 $30 \mathrm{ml}$. 各样品在 $10 \times 20$ 倍下全片计数, 样品计 数两次取平均值计算丰度、生物量. 浮游藻类的定性样品用 $25^{\#}$ 浮游生物网于水下 $0.5 \mathrm{~m}$ 和 $1.5 \mathrm{~m}$ 处采集.

鉴定包括定性和定量的全部标本:在 Olympus CX21 FS1 显微镜下观察、拍照,物种鉴定参考文献 [13-21].

硅藻植物的处理方法:用离心管吸取 $1 \mathrm{ml}$ 标本, 加人等体积的浓硫酸, 混合均匀, 用保鲜膜封住管口, $60^{\circ} \mathrm{C}$ 水浴加热 $1 \mathrm{~h}$; 从水浴锅中取出后振荡, 放置 2 天后, 加人 $1 \mathrm{ml}$ 浓硝酸, 然后加热到无色澄清, 再放置 1 天; 在转速为 3000 转 $/ \mathrm{min}$ 的情况下离心 $10 \mathrm{~min}$, 然后倒去上清液, 加人 $1 \mathrm{ml}$ 蒸馏水混匀, 再混匀、离心、洗涤 3 次. 最后除去上清液, 加人 $1 \mathrm{ml} 95 \%$ 的乙醇混匀; 用吸管吸取一定量的标本, 取干净的载玻片, 将标本点于 载玻片的中央, 用加拿大树胶点在盖玻片上, 盖在标本的正上方, 然后贴上标签, 风干, 这样就制成了硅藻的 


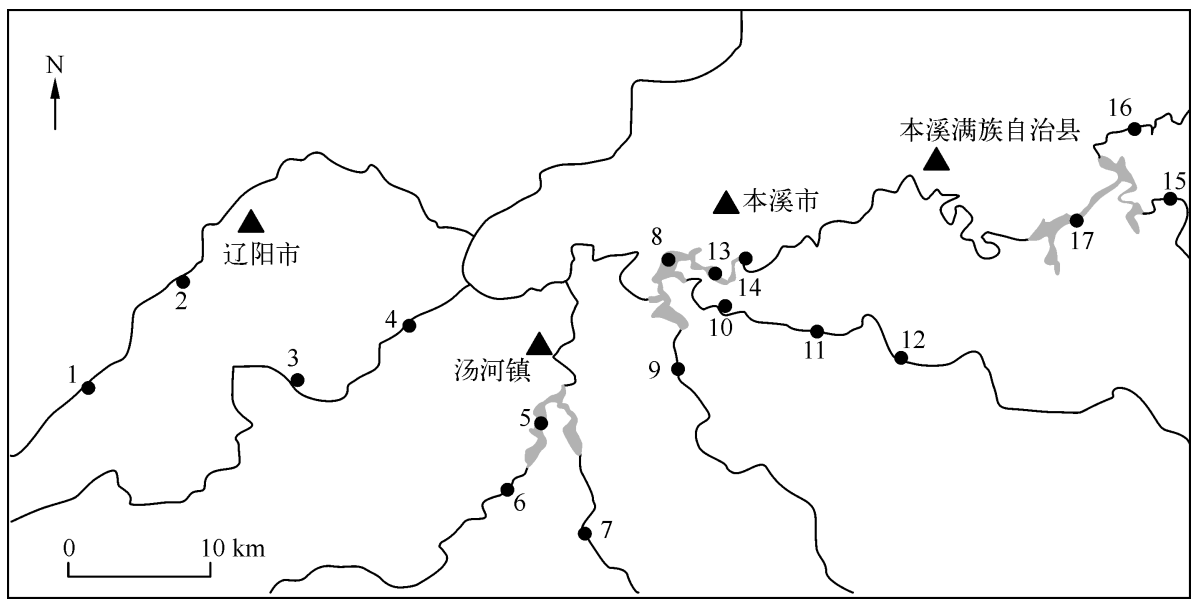

图 1 太子河流域的藻类植物采样点 (1 唐马寨;2 小林子水文站;3 辽阳水文站;4 二焦; 5 汤河水库;6 下达河;7 二道河;8 蓡窝水库;9 细河人库口;10 南甸;11 桥头水文站; 12 红庙;13 白石垃子;14 本溪水文站;15 老关垃子;16 富家;17 观音阁水库）

Fig. 1 Sampling sites of algae of Taizi River catchment

半永久装片 ${ }^{[22]}$.

\section{4 数据处理}

1.4 .1 生物量 藻类植物丰度 $(N)$ 的计算公式为: $N=\frac{C_{\mathrm{s}}}{F_{\mathrm{s}} F_{\mathrm{n}}} \cdot \frac{V}{v} P_{\mathrm{n}}$, 式中, $N$ 为水样中浮游植物 (浮游藻类) 的数量 $($ cells $/ \mathrm{L}), C_{\mathrm{s}}$ 为计数框面积 $\left(\mathrm{mm}^{2}\right), F_{\mathrm{s}}$ 为视野面积 $\left(\mathrm{mm}^{2}\right), F_{\mathrm{n}}$ 为每片计数过的视野数, $V$ 为 $1 \mathrm{~L}$ 水样经 浓缩后的体积 $(\mathrm{ml}), v$ 为计数框容积 $(\mathrm{ml}), P_{\mathrm{n}}$ 为计数所获得的个数.

1.4.2 多样性指数 Jaccard 相似系数 $P=c /(a+b-c)$, 式中, $a 、 b$ 为两个不同季节藻类植物种类数, $c$ 为两 个不同季节的共有种类数.

优势度 $Y=\left(n_{i} / N\right) f_{i}$, 式中, $n_{i}$ 为第 $i$ 种的总个体数, $N$ 为所有物种的总个体数, $f_{i}$ 为第 $i$ 种在各季节出现 的频率 ${ }^{[23]}$.

\section{2 结果与分析}

\section{1 太子河流域藻类植物的种类组成及相似性}

2010 年 9 月一 2011 年 9 月, 通过对太子河流域 12 条干流、5 条支流各站点藻类植物的检测, 共鉴定出藻 类植物 8 门 120 属 328 种 (包括 21 变种), 分属于硅藻门、绿藻门、蓝藻门、甲藻门、裸藻门、金藻门、黄藻门、 隐藻门 (表 1). 藻类植物群落的主体是硅藻, 有 36 属 144 种, 占总体的 $43.77 \%$; 其次是绿藻, 有 49 属 117 种, 占总体的 $35.56 \%$; 其余为蓝藻, 有 22 属 38 种, 占 $11.85 \%$; 甲藻有 4 属 6 种, 占 $1.82 \%$; 裸藻有 3 属 11 种, 占 $3.34 \%$; 金藻有 3 属 5 种, 占 $1.52 \%$; 黄藻有 2 属 4 种, 占 $1.22 \%$; 隐藻最少, 只有 1 属 3 种, 占 $0.91 \%$.

太子河流域藻类植物的种类组成, 以硅藻门为主, 绿藻门次之. 李庆南等从太子河上游南北支到营口人 海口区域, 共鉴定出浮游植物 195 种, 其中硅藻门种类最多, 共鉴定出 97 种, 占总体的 $49.74 \%$; 绿藻门次 之, 共鉴定出 55 种, 占总体的 $28.21 \%$; 蓝藻门居第 3 位, 共鉴定出 25 种, 占总体的 $12.82 \%^{[10]}$. 本研究较之 硅藻门和蓝藻门所占比例略有减少, 绿藻门所占比例增加, 但是硅藻门仍旧占主导地位.

\section{2 太子河流域藻类植物种类组成的季节变化}

太子河流域藻类植物的种类组成的季节变化明显. 2010 年 9 月、2011 年 3、6 和 9 月的藻类植物种类总 数分别为 65 属 123 种、43 属 88 种、99 属 249 种和 46 属 76 种. 藻类植物的总体生长趋势都是从春季到夏季 逐渐生长, 种类数达到最大值, 然后自夏季到秋季, 生长逐渐变得缓慢, 种类数也开始下降 (表 1 ). 
表 1 太子河流域藻类植物主要类群的季节变化

Tab. 1 Seasonal variation of main groups of algae of Taizi River catchment

\begin{tabular}{|c|c|c|c|c|}
\hline 主要类群 & 2010 年 9 月 & 2011 年 3 月 & 2011 年 6 月 & 2011 年 9 月 \\
\hline 硅藻门 & 19 属 32 种 & 19 属 51 种 & 31 属 129 种 & 20 属 42 种 \\
\hline 绿藻门 & 26 属 51 种 & 15 属 26 种 & 43 属 81 种 & 14 属 19 种 \\
\hline 蓝藻门 & 10 属 18 种 & 6 属 8 种 & 17 属 29 种 & 9 属 12 种 \\
\hline 甲藻门 & 2 属 3 种 & 1 属 1 种 & 3 属 3 种 & 1 属 1 种 \\
\hline 金藻门 & 3 属 5 种 & - & 1 属 1 种 & - \\
\hline 黄藻门 & 1 属 1 种 & 1 属 1 种 & 2 属 4 种 & 2 属 2 种 \\
\hline 隐藻门 & 1 属 3 种 & - & - & - \\
\hline 裸藻门 & 3 属 9 种 & 1 属 1 种 & 2 属 2 种 & - \\
\hline
\end{tabular}

一表示未检出.

不但太子河流域藻类植物的种类总数随着季节的变化而变化,其中各门藻类植物的种类组成也存在季 节性变化. 硅藻门种类 2011 年 3-6 月从 51 种增长到了 129 种之多, 6-9 月种类数又开始减少,到 2011 年 9 月时,种类数仅为 42 种 (表 1). 桥弯藻属 (Cymbella)、舟形藻属 (Navicula)、羽纹藻属 (Pinnularia)、异极藻 属 (Gomphonema) 在 3 月份比较繁盛, 而且种类数也比较多, 分别达到了 7、10、4 和 6 种. 而各种藻类在 6 月 (夏季) 都达到了种类及数量的最大值,如舟形藻属 22 种、桥弯藻属 15 种、菱形藻属 (Nitzschia) 13 种、异极 藻属 12 种、羽纹藻属 10 种, 另外还有一些藻类植物的种类数达到了很高值, 如针杆藻属 (Synedra) 达到 8 种、脆杆藻属 (Fragilaria) 和双菱藻属 (Sururella) 也都达到 6 种. 本研究在夏季的调查结果与殷旭旺等 ${ }^{[11]}$ 在 2009 年 8 月及李庆南等 ${ }^{[10]}$ 在 2009 年 5-8 月的调查结果相似, 都是硅藻门种类最多,绿藻门次之, 蓝藻门居 第 3 位, 其它门的藻类只占一小部分比例. 而在 9 月 (秋季), 藻类种类数量和丰富程度都有所降低, 只有舟 形藻属和桥弯藻属种类数较多, 都达到了 7 种, 而菱形藻属只有 4 种, 还居于硅藻门种类数的第 3 位. 绿藻门 种类数的发展趋势与硅藻门的一致, 3 月份时绿藻门种类数为 26 种, 比较繁盛的种类有栅藻属 (Scenedesmus $) 4$ 种、棒形鼓藻属 (Gonatozygon) 3 种、毛枝藻属 (Stigeoclonium) 3 种和新月藻属 (Closterium) 3 种; 6 月份 各个种类数也都达到了最大值, 有 82 种之多, 其中栅藻属最多, 达到了 7 种, 而后依次是 5 种微狍藻属 $(M i-$ crospora) 和鼓藻属 (Cosmarium) ,4 种纤维藻属 (Ankistrodesmus)、水绵藻属 (Spirogyra)、新月藻属和盘星藻属 (Pediastrum), 3 种柱形鼓藻属 (Peniun)、毛枝藻属和棒形鼓藻属. 而在 9 月份, 藻类种类数仅为 19 种, 还要 低于春季时的种类数, 只有栅藻属达到了 3 种. 蓝藻门和黄藻门的种类数的发展趋势是一样的,都是在春季 到夏季逐渐生长达到了最高值, 而后由夏季到秋季种类数逐渐减少, 但是在秋季, 种类数仍然高于春季. 蓝 藻门春季种类数为 9 种, 分别属于色球藻属 (Chroococcus) 和颤藻属 (Oscillatoria); 夏季种类数为 31 种,色球 藻属和颤藻属都达到了 5 种; 在秋季, 藻类种类总数为 13 种, 种类数比较多的是色球藻属 2 种、颤藻属 2 种 和鱼腥藻属 (Anabaena) 2 种. 黄藻门在 3 月份有 1 种, 为拟气球藻 (Botydiopsis arhiza Borzi); 6 月份有 4 种, 分 别是黄丝藻 (Tribonema sp.) 、小型黄丝藻 (Tribonema minus (Will.) Haz.)、近缘黄丝藻 (Tribonema affine G. S. West) 和拟气球藻; 9 月份为 2 种, 分别是小型黄丝藻和拟气球藻. 甲藻门在 2011 年 3 月和 2011 年 9 月 各检出 1 种,为变形甲藻 (Dinamoebidium varians Pascher)；2011 年 6 月检出 3 种,为二形角甲藻 (Peridinium bipes Stein)、角甲藻 (Ceratium hirundinella (Müll. ) Schr.) 和变形甲藻;金藻门只在 2011 年 6 月检出了 1 种, 为密集雉囊藻 (Dinobryon sertularia Ehr. ) ; 裸藻门在 2011 年 9 月检出了 9 种, 而 2011 年 3 月检出了 1 种尾棘 囊裸藻 (Trachelomonas armata (Ehr.) Stein),6 月份检出 2 种, 分别为尾裸藻 (Euglena caudate Hübn.) 和尾 棘囊裸藻; 隐藻门只在 2010 年 9 月检出了 3 种, 为尖尾蓝隐藻 (Chroomonas acuta Uterm. )、啮蚀隐藻 (Chroomonas erosa Ehr.) 和卵形隐藻 (Chroomonas ovate Ehr. ).

藻类植物种类的采样点间差异较小, 如 2011 年 3 月二焦的藻类种类总数为 53 种, 观音阁藻类种类总数 为 46 种, 在这 2 个采样点的相同藻种数就有 30 种, 达到了观音阁藻类种类总数的 $65.22 \%$. 但是各季节之 间种类数的差异较大, 2011 年 3 月藻类种类总数为 88 种,2011 年 6 月为 249 种, 2010 年 9 月为 122 种,2011 年 9 月为 76 种, 由此可见, 在夏季和秋季藻类植物种类比较丰富, 而春季的藻类植物种类相对较少. 不但各 
个季节藻类植物的种类数差异较大, 在藻类植物的种类组成上也有很明显的差别. 因此, 本文计算了太子河 流域藻类植物的 Jaccard 种类相似性指数 (表 2). 结果表明, 太子河流域的藻类植物的 Jaccard 种类相似性 指数范围在 $0.19 \sim 0.46$ 之间. 其中, 春季和秋季的相似性指数最高, 为 0.46 ; 春季和夏季的相似性指数次 之, 为 0.31 ; 夏季和秋季的种类差异最大,为 0.29 . 与 2011 年秋季和 2011 年春、夏两季的相似性指数相比, 2010 年秋季和 2011 年春、夏两季的相似性指数要低, 分别为 $0.19 、 0.17$. 虽然如此, 但是不论怎么变化, 各 个季节间的种类相似性指数都小于 0.50 , 这就说明太子河流域藻类植物的季节更替明显, 所以本文讨论太 子河流域藻类植物群落的季节性变化是非常有必要的.

表 2 太子河不同季节藻类植物种类的相似性指数

Tab. 2 Jaccard index of algae species between seasons in Taizi River

\begin{tabular}{cccccc}
\hline & 春季/夏季 & 春季/2010 年秋季 & 春季/2011 年秋季 & 夏季/2010 年秋季 & 夏季/2011 年秋季 \\
\hline 种类数 & $88 / 249$ & $88 / 121$ & $88 / 76$ & $243 / 121$ & $249 / 76$ \\
相同种类数 & 80 & 34 & 52 & 53 & 74 \\
Jaccard 指数 & 0.31 & 0.19 & 0.46 & 0.17 & 0.29 \\
\hline
\end{tabular}

\section{3 太子河流域藻类植物丰度的分布及季节变化}

太子河流域藻类植物平均丰度自 2011 年 3 月份的 $1.36 \times 10^{7}$ cells $/ \mathrm{L}$ 增长到 2011 年 6 月份的 $6.80 \times 10^{7}$ cells $/ \mathrm{L}$, 达到最高, 到 2011 年 9 月略有下降, 为 $3.29 \times 10^{7} \mathrm{cells} / \mathrm{L} .2010$ 年 9 月太子河流域藻类植物的平均丰 度远远高于 2011 年 9 月, 甚至与 2011 年 6 月的平均丰度值相近, 达到了 $6.61 \times 10^{7} \mathrm{cells} / \mathrm{L}$. 这说明洪水的发 生促进了藻类植物的大量生长, 尤其是绿藻门的植物.

太子河流域藻类植物的主要类群丰度的季节变化非常明显 (表 3). 硅藻门丰度在 3 月达到了 $18.98 \times$ $10^{5} \mathrm{cells} / \mathrm{L}$, 占总丰度的 $13.95 \%$, 到 6 月增长到最高, 达到了 $210.47 \times 10^{5} \mathrm{cells} / \mathrm{L}$, 占总丰度的比例也大幅提 高, 为 $30.94 \%$, 甚至超过了绿藻门所占总丰度的比例. 9 月丰度值降到了 $97.62 \times 10^{5} \mathrm{cells} / \mathrm{L}$, 仅占总丰度值 的 $29.61 \%$, 但是仍然明显高于 3 月, 这与藻类植物平均丰度的季节变化态势相一致. 绿藻门和蓝藻门的细 胞丰度与藻类植物平均丰度的季节变化态势也是一致的, 但是所占总丰度值的比例变化却不相同. 绿藻门 植物在 3 月丰度占总丰度的 $49.36 \%$, 到 6 月比例下降到 $28.82 \%, 9$ 月所占比例又升高到了 $37.54 \%$. 虽然 9 月所占的比例值有很明显的降低, 但实际上丰度值是大幅增长的, 为 3 月的 2 倍左右. 蓝藻门植物 3-9 月丰 度占总丰度的比例从 $36.68 \%$ 降到 $29.85 \%$, 但是其细胞丰度却在 6 月最大 $\left(238.73 \times 10^{5} \mathrm{cells} / \mathrm{L}\right), 9$ 月次之 $\left(98.39 \times 10^{5} \mathrm{cells} / \mathrm{L}\right), 3$ 月最低 $\left(49.92 \times 10^{5} \mathrm{cells} / \mathrm{L}\right)$. 甲藻门和黄藻门在各个季节中都出现, 与藻类植物平均 丰度的季节变化态势相一致, 占总丰度值的比例变化与硅藻门植物一致. 裸藻门植物在 2011 年 9 月未检测 到, 说明裸藻门植物在秋季出现的概率很小. 2010 年 9 月, 裸藻门植物的丰度达到了 $7.81 \times 10^{5} \mathrm{cells} / \mathrm{L}$, 远远 超过了 2011 年 3 月和 6 月, 金藻门和隐藻门植物只在 2010 年 9 月检测到, 可能是受到了洪水的影响, 因此 只把 2010 年 9 月的数据作为参考.

\section{4 太子河流域藻类植物的优势种和季节变化}

浮游植物优势种在河流生态系统中有着重要作用, 优势种的组成、变化和优势度可以很好地反映水质 状况. 根据太子河流域藻类植物丰度的种间分配情况, 选取优势度 $Y>0.02$ 的种类作为藻类植物群落的优 势种. 太子河流域藻类植物优势种群的季节演替明显, 差异较大 (表 4). 全部 22 个优势种仅有 13 种在 2 个 以上季节中出现, 巨颤藻和链丝藻为 3 季优势种, 小颤藻、细链丝藻、普通水绵、变异直链藻和小型黄丝藻为 6 月和 9 月优势种, 池生毛枝藻、偏生毛枝藻和尺骨针杆藻为 3 月和 6 月优势种, 扁圆舟形藻、简单舟形藻和 双头菱形藻为 3 月和 9 月优势种, 其余种类的优势地位是单一季节性的.

硅藻门种类繁多, 一直占有一定的优势, 主要是由于其多为狭冷性物种, 适合生活在较冷的环境中 ${ }^{[24]} \cdot 3$ 月和 9 月时, 河流水温较低, 很多狭温嗜暖性种类难以在湖中生长; 其次可能是因为硅藻门属于比较原始的 门类, 也更易于生存. 而在 6 月, 由于光照增强, 温度升高, 有机质分解旺盛, 蓝藻和绿藻门中的一些物种大 量繁殖, 并占据了一定的优势. 9 月, 北方天气转凉, 硅藻门植物也开始大范围生长, 成为又一优势种群; 绿藻 门的种群优势仍然存在. 
表 3 太子河流域藻类植物主要类群丰度的季节变化

Tab. 3 Seasonal variation of abundance of the main algae at waters in Taizi River catchment

\begin{tabular}{|c|c|c|c|c|c|c|c|c|}
\hline \multirow[b]{2}{*}{ 主要类群 } & \multicolumn{2}{|c|}{2010 年 9 月 } & \multicolumn{2}{|c|}{2011 年 3 月 } & \multicolumn{2}{|c|}{2011 年 6 月 } & \multicolumn{2}{|c|}{2011 年 9 月 } \\
\hline & $\begin{array}{c}\text { 丰度/ } \\
\left(\times 10^{5} \text { cells } / \mathrm{L}\right)\end{array}$ & 比例 $/ \%$ & $\begin{array}{c}\text { 丰度/ } \\
\left(\times 10^{5} \text { cells } / \mathrm{L}\right)\end{array}$ & 比例 $/ \%$ & $\begin{array}{c}\text { 丰度/ } \\
\left(\times 10^{5} \text { cells } / \mathrm{L}\right)\end{array}$ & 比例 $/ \%$ & $\begin{array}{c}\text { 丰度/ } \\
\left(\times 10^{5} \text { cells } / \mathrm{L}\right)\end{array}$ & 比例 $/ \%$ \\
\hline 硅藻门 & 256.58 & 38.83 & 18.98 & 13.95 & 210.47 & 30.94 & 97.62 & 29.61 \\
\hline 绿藻门 & 293.43 & 44.41 & 67.18 & 49.36 & 196.01 & 28.82 & 123.76 & 37.54 \\
\hline 蓝藻门 & 94.28 & 14.27 & 49.92 & 36.68 & 238.73 & 35.10 & 98.39 & 29.85 \\
\hline 甲藻门 & 3.41 & 0.52 & 0.0017 & 0.001 & 0.07 & 0.01 & 0.009 & 0.002 \\
\hline 金藻门 & 2.01 & 0.30 & - & - & - & - & - & - \\
\hline 黄藻门 & 0.20 & 0.03 & 0.0023 & 0.002 & 33.98 & 5.00 & 9.86 & 2.99 \\
\hline 隐藻门 & 3.07 & 0.46 & - & - & - & - & - & - \\
\hline 裸藻门 & 7.81 & 1.18 & 0.006 & 0.004 & 0.915 & 0.13 & - & - \\
\hline
\end{tabular}

一表示未检出.

\section{表 4 太子河流域藻类植物优势种 $(Y>0.02)$ 及优势度}

Tab. 4 Dominant algae species and their dominance of Taizi River catchment

\begin{tabular}{|c|c|c|c|c|}
\hline 优势种 & 2010 年 9 月 & 2011 年 3 月 & 2011 年 6 月 & 2011 年 9 月 \\
\hline 巨颤藻 ( Oscillatoria princeps Vauch. ) & 0.02 & 0.05 & 0.02 & 0.07 \\
\hline 小颤藻 ( Oscillatoria tenuis Ag. ) & - & - & 0.10 & 0.07 \\
\hline 美丽颤藻 (Oscillatoria formosa Bory) & - & & 0.07 & \\
\hline 链丝藻( Hormidium flaccidum ( Kütz. ) Br. ) & & 0.04 & 0.05 & 0.04 \\
\hline 细链丝藻 (Hormidium subtile (Kütz.) Heer. ) & - & & 0.02 & 0.06 \\
\hline 环丝藻 (Ulothrix zonata (Web. et Mohr) Kütz. ) & & & 0.04 & \\
\hline 偏肿桥弯藻 ( Cymbella tumida) & 0.03 & - & - & 0.02 \\
\hline 扁圆舟形藻 (Navicula placentula (Ehr. ) Grun. ) & 0.02 & 0.03 & - & \\
\hline 简单舟形藻 ( Navicula simplex Krassk. ) & - & 0.03 & - & 0.02 \\
\hline 英吉利舟形藻 (Navicula anglica Ralfs) & 0.02 & & - & 0.03 \\
\hline 双头菱形藻 ( Nitzschia amphibian Grun. ) & 0.03 & 0.02 & - & 0.02 \\
\hline 池生毛枝藻 (Stigeoclonium stagnatile (Haz. ) Coll. ) & & 0.05 & 0.03 & \\
\hline 偏生毛枝藻 (Stigeoclonium subsecundum (Kütz.) Haz.) & & 0.03 & 0.06 & \\
\hline 普通水绵 (Spirogyra communis (Hass.) Kütz.) & 0.03 & - & 0.05 & 0.03 \\
\hline 美貌水绵( Spirogyra pulchrifigurata Jao) & & & 0.02 & \\
\hline 普通等片藻 (Diatoma vulgare) & & 0.02 & - & \\
\hline 变异直链藻 (Melosira varians Ag. ) & - & & 0.05 & 0.04 \\
\hline 螺旋鞘丝藻 ( Lyngbya contarta Lemm) & & & & 0.03 \\
\hline 尺骨针杆藻 (Synedra ulna ( Nitzsch. ) Ehrenb. ) & & 0.04 & 0.02 & - \\
\hline 窗格平板藻 (Tabellaria fenestrata ( Lyngby. ) Kütz. ) & - & & & 0.02 \\
\hline 维利微狍藻 (Microspora willeana Lag. ) & 0.03 & - & 0.02 & - \\
\hline 小型黄丝藻 (Tribonema minus (Will. ) Haz.) & & - & 0.03 & 0.04 \\
\hline
\end{tabular}

一表示优势度 $Y<0.01$.

殷旭旺等 ${ }^{[11]}$ 在 2009 年 8 月鉴定出的优势种类种类包括: 变异直链藻、普通等片藻、偏肿桥弯藻、胡斯特 桥弯藻 ( C. hustedtii)、嗀头舟形藻 (Navicula cryptocephala)、橄榄绿色异极藻 (Gomphonema olivaceum)、极细微 曲壳藻 (Achnanthes minutissima)、尖针杆藻 (Synedra acus)、肘状针杆藻 ( S. ulna) 、肘状针杆藻尖潒变种 ( $S$. ulna oxyrhynchus)、谷皮菱形藻 (Nitzschia palea) 、扁圆卵形藻 (Cocconeis placentula)、四尾栅藻 ( Scenedesmus quadricauda)、小颤藻和小席藻(Phormidium tenus). 本文夏季鉴定出的优势种有巨颤藻、小颤藻、美丽颤藻、 链丝藻、细链丝藻、环丝藻、池生毛枝藻、偏生毛枝藻、普通水绵、美貌水绵、变异直链藻、尺骨针杆藻、维利微 孢藻和小型黄丝藻, 这与殷旭旺等 ${ }^{[11]}$ 的调查结果有所出人是因为本文的调查在 6 月份, 水温呈上升趋势, 而 他们调查时间在 8 月末,水温呈下降趋势, 硅藻门种类的一些狭冷性物种逐渐呈现明显趋势, 所以 8 月的调 
查中硅藻门种类占优势种类的大部分.

\section{3 结论}

在太子河流域共鉴定出该藻类植物 8 门 120 属 328 种 (包括 21 变种). 藻类植物群落中硅藻最多,有 36 属 144 种, 占总体的 $43.77 \%$; 其次是绿藻, 有 49 属 117 种, 占 $35.56 \%$; 其余蓝藻有 22 属 38 种, 占 $11.85 \%$; 甲藻有 4 属 6 种, 占 $1.82 \%$; 裸藻有 3 属 11 种, 占 $3.34 \%$; 金藻有 3 属 5 种, 占 $1.52 \%$; 黄藻有 2 属 4 种, 占 $1.22 \%$; 隐藻最少, 只有 1 属 3 种, 占 $0.91 \%$.

藻类植物种类的采样点间差异较小. 太子河流域藻类植物的 Jaccard 种类相似性指数结果得出其相似 性指数范围为 $0.19 \sim 0.46$, 这就说明太子河流域藻类植物的季节更替明显, 因此讨论太子河流与藻类植物 群落的季节性变化是非常必要的.

太子河流域藻类植物平均丰度自春季的 $1.36 \times 10^{7}$ cells $/ \mathrm{L}$ 增长到夏季的 $6.80 \times 10^{7} \mathrm{cells} / \mathrm{L}$, 达到最高 值, 到秋季略有下降, 为 $3.29 \times 10^{7}$ cells/L. 2010 年 9 月的太子河流域藻类植物的平均丰度远远高于 2011 年 9 月, 为 $6.61 \times 10^{7}$ cells $/ \mathrm{L}$. 这说明, 洪水的发生对藻类植物的生长非但没有起到反作用, 甚至使得藻类植物 大量的生长, 尤其是绿藻门的植物.

根据太子河流域藻类植物丰度的种间分配情况, 选取优势度 $Y>0.02$ 的种类作为藻类植物群落的优势 种, 结果显示其优势种群的季节演替明显. 全部 22 个优势种仅有 13 种在 2 个以上季节中出现, 巨颤藻、链丝 藻为 3 季优势种, 小颤藻、细链丝藻、普通水绵、变异直链藻、小型黄丝藻、池生毛枝藻、偏生毛枝藻、尺骨针 杆藻、扁圆舟形藻、简单舟形藻、双头菱形藻为 2 季优势种, 其余种类的优势地位是单一季节性的.

\section{4 参考文献}

[1] 张 远, 陈立斌, 渠晓东等. 辽宁太子河大型水生植物的群落特征及其与环境的关系. 植物科学学报,2011,29(5): 552-560.

[2] 胥学鹏,张 峥,卢 雁. 太子河水质污染时空异质性分析. 现代农业科技,2011,(5):266-268.

[3] 杜 斌,冯金鹏. 太子河流域水污染现状分析. 吉林水利,2005,(12):14-17.

[4] 沈 拥,何丽莉. 太子河流域辽阳段河流水质污染状况分析. 环境保护科学,2009,35(3):19-22.

[ 5 ] 姜 雄. 朴文福. 关于本溪市太子河水系的污染调查与数学统计分析. 环境研究与检测, 2006,19(2):37-39.

[6] 赵彦霞,蔡巧玲,赵井泉. 太子河“本溪水段”水质污染的浮游植物的影响. 环境保护科学, 1993,64:57-62.

[7] 苏 玉, 王东伟, 文 航等. 太子河流域本溪段水生生物的群落特征及其主要水质影响因子分析. 生态环境学报, $2010,19(8): 1801-1808$.

[ 8 ] 李 悦,马溪平, 李法云等. 太子河北支河岸带植物群落特征及其物种多样性研究. 辽宁农业科学, 2011, (5):1-6.

[9] 邱春刚,刘丙阳,刘旭光等. 汤河水库春季浮游生物的群落结构及空间分布. 水产科学,2007,26(4):222-228.

[10] 李庆南, 赵 文, 殷旭旺等. 辽河太子河水系的浮游植物种类多样性研究. 大连海洋大学学报, 2011,26(4): 321-327.

[11］殷旭旺,渠晓东,李庆南等. 基于着生藻类的太子河流域水生态系统健康评价. 生态学报,2012,32(6):1677-1691.

[12］金相灿,屠清瑛,章宗涉等. 湖泊富营养化调查规范. 北京:中国环境科学出版社, 1990.

[13] 魏印心. 中国淡水藻志 (第七卷) : 绿藻门双星藻目中带鼓藻科鼓藻目鼓藻科第 1 册. 北京:科学出版社,2003.

[14] 施之新, 王全喜, 谢树莲等. 中国淡水藻志 (第六卷) : 裸藻门. 北京:科学出版社, 1999 .

[15] 毕列爵, 胡征宇. 中国淡水藻志 (第八卷) : 绿球藻门绿球藻目 (上). 北京:科学出版社,2004.

[16] 王全喜, 吕淑慧, 包文美. 东北淡水藻类的研究 I 栅藻属 Scenedesmus. 哈尔滨师范大学: 自然科学学报, 1991,7 (生 物专辑) :99-112.

[17］周凤霞,陈剑虹. 淡水微型生物图谱. 北京: 化学工业出版社, 2008 .

[18] 胡鸿钧,李尧英,魏印心等. 中国淡水藻类. 上海: 上海科学技术出版社, 1980 .

[19] 福迪 B, 罗迪安. 藻类学. 上海: 上海科学技术出版社, 1980 .

[20] Kormarek J, Fott B. Chlorococcales. In: Huber-Pestalozzi G ed. Das Phytoplankton des Susswassers 7/1. Stut tgart: E S chwe-izerbarts'che Verlagsbuchhand lung, 1983.

[21] Uherkovich G. Die Scenedesm us-Arten Ungarn s. Budapest: Akadem iaiK iado, 1966.

[22] 谢树莲,张瑜娥,李晓红. 漳泽水库的绿藻植物. 山西大学学报,1996,19(4):463-466.

[23] 王云龙,袁 骐, 沈新强. 长江口及邻近水域春季浮游植物的生态特征. 中国水产科学, 2005,12(3):300-306.

[24] Morais P, Chcharo AM, Barbosa A et al. Phytoplankton dynamics in a coastal saline lake (SE-Portugal). Acta Oecologi$c a, 2003,24(1): 87-96$. 